\title{
Mobile Learning with STEM Approach in Physics Learning
}

\author{
Asmiliyah $^{1 *}$, Khaerudin ${ }^{2}$, Etin Solihatin ${ }^{3}$ \\ 1,2 Postgraduate Educational Technology, State University of Jakarta, Jakarta, Indonesia
}

\section{A R T I CLE I N F O}

Article history:

Received May 04, 2021

Revised May 05, 2021

Accepted September 24, 2021

Available online November 25, 2021

\section{Kata Kunci :}

Pembelajaran Seluler; pendekatan

STEM; Pembelajaran Fisika

Keywords:

Mobile Learning; STEM approach; Physics Learning

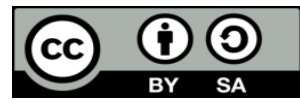

This is an open access article under the $\underline{C C}$ BY-SA license.

Copyright (C) 2021 by Author. Published by Universitas Pendidikan Ganesha

\begin{abstract}
A B S T R A K
Sebagian besar pembelajaran fisika yang dilakukan di sekolah lebih menekankan pada pengetahuan dan pemahaman materi saja, tanpa mengembangkan keterampilan pemecahan masalah dan menerapkan konsep dalam konteks kehidupan nyata. Siswa masih sering menggunakan pendekatan plug \& chug dan memory based dalam menyelesaikan soal fisika. Hal ini menyebabkan siswa mampu menyelesaikan masalah kuantitatif yang sederhana tetapi kurang memiliki kemampuan untuk menyelesaikan masalah yang lebih kompleks. Penelitian ini bertujuan untuk menghasilkan mobile learning dengan pendekatan STEM yang layak dan efektif untuk pelajaran fisika. Penelitian ini merupakan Research and Development (R\&D) dengan menggunakan model Alessi dan Trollip. Model tersebut terdiri dari tiga tahap pengembangan, yaitu perencanaan, perancangan dan pengembangan. Metode yang digunakan untuk mengumpulkan data yaitu wawancara dan kuesioner. Instrument yang digunakan untuk mengumpulkan data yaitu kuesioner. Teknik yang digunakan untuk menganalisis data yaitu analisis deskriptif kualitatif dan kuantitatif. Berdasarkan uji kelayakan yang dilakukan oleh ahli desain pembelajaran, ahli media dan ahli materi serta uji keefektifan secara langsung menggunakan produk dengan tujuan nyata, diperoleh bahwa aplikasi mobile learning dengan pendekatan STEM layak dan efektif digunakan dalam pembelajaran fisika. Menggabungkan pendekatan STEM dan model pembelajaran berbasis masalah dengan pembelajaran mobile dapat menjadi salah satu pelajaran yang cocok untuk generasi. Hasil penelitian tersebut menunjukkan bahwa pengembangan aplikasi mobile learning cross platform dengan pendekatan STEM layak dan efektif dalam pembelajaran fisika.
\end{abstract}

\section{A B S T R A C T}

Most of the physics done in schools is more about learning on knowledge and understanding of the material, without developing problem-solving skills and applying concepts in real-life contexts. Students still often use the plug \& chug and memory-based approach in solving physical problems. It causes students to be able to solve simple quantitative issues but cannot solve more complex issues. This study aims to produce mobile learning with a feasible and practical STEM approach for physics lessons. This research is a Research and Development (R\&D) using the Alessi and Trollip model. The model consists of three stages of development, namely planning, design, and development. The methods used to collect data are interviews and questionnaires. The instrument used to collect data is a questionnaire. The technique used to analyze the information is descriptive qualitative and quantitative analysis. Based on trials conducted by learning design experts, media experts, and materials experts and direct effectiveness tests using products with tangible goals. It was found that mobile learning applications with a STEM approach were feasible and effective in physical learning. Combining STEM approaches and problembased learning models with mobile learning can be one of the suitable lessons for making. This study indicates that the development of cross-platform mobile learning applications with a STEM approach is feasible and effective in learning physics.

\section{INTRODUCTION}

Senior High School (SMA) is a secondary education level that prioritizes the preparation of students to continue higher education with specialization (Afriyanti et al., 2021; Anwar et al., 2020; Astra et al., 2015). The realization of this specialization has been carried out from class $X$ with three specialization programs, namely a specialization in Social Sciences (IPS), a specialization in Mathematics and Natural Sciences (MIPA) and a specialization in Culture and language. Each specialization program has subject characteristics. Physics is one of the characteristics of the subject of the Mathematics and Natural Sciences specialization program which aims to make students have the ability to master concepts, principles of physics and develop thinking skills that are useful for solving problems in everyday life (Darmawan et al., 2020; Diani et al., 2018; Rante et al., 2013). The difficulty faced by most students is in interpreting various concepts and principles of physics (Ekici, 2016; Gunada et al., 2017). Because they are required to be able to interpret the concepts and principles of physics correctly and not vaguely. Interpreting the concepts and 
principles of physics is obtained through problem solving, observations and experiments that describe and explain the material (concepts and principles) of physics about phenomena that occur in nature (Gunawan et al., 2019; Juraini et al., 2017; Mutakinati et al., 2018).

Most of the physics learning carried out in schools emphasizes knowledge and understanding of the material only, without developing problem-solving skills and applying concepts in real-life contexts (Desnita \& Susanti, 2017; Sudirman et al., 2020; Sulani et al., 2020). Even in learning, students still often use the plug and chug approach (they tend to enter numbers into the formula without considering the physical meaning of the equation or formula used) and memory based in solving physics problems (Kortemeyer, 2016). This causes students to be able to solve simple quantitative problems but lack the ability to solve more complex problems (Azizah et al., 2015; Nuraziza \& Suwarma, 2018). There are still many students who have difficulty in learning Physics. This of course has an impact on the ability and low learning outcomes of students (Nuraziza \& Suwarma, 2018; Sudirman et al., 2020; Syahrowardi \& Permana, 2016). So the teacher must use an appropriate learning model so that it is easier for students to understand the learning material (Priani et al., 2019; Sa'diyah, 2020). One of the models that can be used is problem based learning.

Problem Based Learning (PBL) is a learning model based on the principle of using problems as a starting point for the acquisition and integration of new knowledge. PBL is a learner-centered learning model by exposing these students to authentic and meaningful problems (Arends, 2015; Rahayuni, 2016; Sudana et al., 2019). Problem solving is a component of a problem-based approach. With this learning model, students from the beginning have been exposed to various problems holistically in real life. Problem solving abilities in physics learning are not only related to how the students' ability to use formulas for solving mathematical problems but also the ability to solve science (physics) concepts with engineering and technology (Darmawan et al., 2020; Heong et al., 2011; Polyanin et al., 2011). The STEM approach is an infinite amalgamation of content and concepts from a variety of STEM disciplines (Kattayat et al., 2017; Roebianto, 2020). The Science, Technology, Engineering and Mathematics approach is an approach that combines four aspects (science, technology, engineering and mathematics) in learning (Torlakson, 2014). With the concept of integrating four aspects in the STEM approach, problem solving can be done holistically (Felder \& Brent, 2016; Guzey et al., 2016; Parno et al., 2019). Combining problem-based learning models with STEM approaches, students can have more complex problem solving skills in a real-life context (Elsayary et al., 2015; Widayanti et al., 2019). This learning model is suitable to be applied to high school students.

SMA level students are currently generation Z students with births around 1995 - 2010 (Bencsik et al., 2016; Sa'pang \& Purbojo, 2020). Generation Z prefers to use smartphones to access the internet rather than using computers or laptops (Seemiller, Corey, 2019; Zabelina \& Silvia, 2020). Generation Z's mainstay is the internet, which is an abundant source of support for decision making (Maulina et al., 2020). As time goes by, educators must abandon the old ways in order to successfully guide generation $\mathrm{Z}$ to face the future. It is very necessary to innovate in teaching $Z$ generation children, because they have a different concept of thinking. Generation Z's environment is not only the real world, but also the virtual realm. The discovery of new technologies is one of the factors supporting the increase in new needs in all fields, including in the field of education. New innovations are born along with the development of technology and the needs of educators and especially students. Learning using smartphones can be an alternative learning for Generation Z (Maulina et al., 2020; Seibert, 2020).

Mobile learning has many benefits: continuous, ongoing, fexible learning; it enables time for refection; it facilitates informal and formal learning; it supports personalization; it is readily available; ubiquitous; contextual and relevant; it provides ubiquitous access and supports user-generated media (Buchanan et al., 2019; Darmaji et al., 2019; Zhang, 2015). The purpose of mobile learning development itself is the process of learning all the time (long life learning), students can be more active in the learning process, effectively time because if applied in the learning process then students do not need to be present in the classroom just to collect tasks, enough tasks are sent through the application on a mobile phone that will indirectly improve the quality of the learning process itself. Mobile learning has a role in helping to display physical phenomena. In the world of education, sometimes there are many abstract and imaginative things that are difficult for students to think about (Handayani et al., 2021; Kattayat et al., 2017; Rahmat et al., 2019).

Thermodynamics is one of the abstract and elusive physical materials of students. By utilizing mobile learning, abstract things can be presented through videos, virtual labs, animations or simulations (Nikolopoulou \& Kousloglou, 2019; Widayanti et al., 2019). So that students easily understand physics material and improve the quality of learning (García-Martínez et al., 2019). Mobile learning is effectively used in science learning when combined with learning approaches and problem-based learning models (Bano et al., 2018; Nikolopoulou \& Kousloglou, 2019). Characteristics of high school students who are close 
to gadgets and lack of problem solving skills are the basis for the development of mobile learning applications combined with problem-based learning models and STEM approaches. The development of mobile learning with the STEM approach has been carried out by Ngabekti with the edmodo application on ecosystem material with an online database (Ngabekti et al., 2019). The results of these studies indicate that the development of mobile learning with the STEM approach is effective in learning biology. The STEM approach and the problem based learning model are suitable for mobile learning physics, because learning physics requires the ability to solve problems, the mathematical ability to use physics formulas, the technical skills when making observations or experiments and the ability to use technology (Argaw et al., 2017; Duran et al., 2015; Shin et al., 2017). This research aims to produce mobile learning with a viable and effective STEM approach to physics lessons.

\section{METHODS}

This research is a Research and Development (R\&D) using the Alessi and Trollip models developed by Stephen M. Alessi and Stanley R. Trollipand the waterfall model was developed by Sommerville Ian. The model consists of three stages of development, namely planning, design and development and at the development stage combined with the waterfall model (Alessi \& Trollip, 2001; Sommerville, 2016). The product of development in this study is a cross-platform mobile learning application with a STEM approach and a problem-based learning model on thermodynamic material. This research and development uses Alessi and Trollip and waterfall models. The steps in this development can be modified and adapted to the needs of development research. This research was conducted in class XI MIPA at SMA YP IPPI. The following is a mobile learning development plan with the STEM approach as follows: (a) Planning (Product Planning) includes define the scope, identify learner characteristics, establish the constraints, cost the project, produce a planning document, determine and collect resources, and conduct initial brainstorming. (b) Design (Product Design) includes develop initial content ideas, conduct task and concept analyzes, do a preliminary program description,create flowcharts, storyboards, and scripts and create database and user interface. (c) Development includes preparing the text, creating graphics, produce audio and video, assembling the pieces,writing program code and converting application,do an alpha test, make revisions, do a beta test,make revisions, validate. The methods used to collect data are interviews and questionnaires. The instrument used to collect data is a questionnaire. The technique used to analyze the information is descriptive qualitative and quantitative analysis.

\section{RESULT AND DISCUSSION}

\section{Results}

Integrating mobile learning applications with problem-based learning models and STEM approaches is one of today's learning alternatives (Tseng et al., 2018). The mobile learning application developed using the RASE learning design framework namely Resources, Activity, Support and Evaluation (Churchill, Fox, et al., 2016). The RASE learning design framework is adapted to the menus in the development of mobile learning which will be developed in this research, namely resources (material menu) in the material menu there are learning objectives, materials in the form of video, animation or simulation, activity (practice menu), Support (discussion menu) and Evaluation (assessment menu) (Churchill, Fox, et al., 2016; Widayanti et al., 2019). The mobile learning application is developed with a cross platform (xamarin) and a hybrid database (online and offline merging) so that students can access the application without being limited by the system base (android, iOS) and their mobile database (Bartling et al., 2016). There are two mobile learning designs in this study, namely the mobile learning design for teachers and the mobile learning design for students (Wang, 2018). The display of Student's Main Menu and Teacher's Main Menu is presented in Figure 1.

The results of these studies indicate that the development of application mobile learning with the STEM approaches combination problem-based learning models on thermodynamics material is worth and effective in learning physics. The feasibility test in this study involved learning design experts, media experts and material experts. The results obtained that this mobile learning application is worth using in physics learning. At the summative evaluation stage, the product that has been revised at the development stage is then implemented at its actual target. During implementation, a measurement of the achievement of learning objectives was carried out. The results showed there was an improvement in students' problem solving skills. This measurement is carried out to determine the effectiveness of the product being developed. 


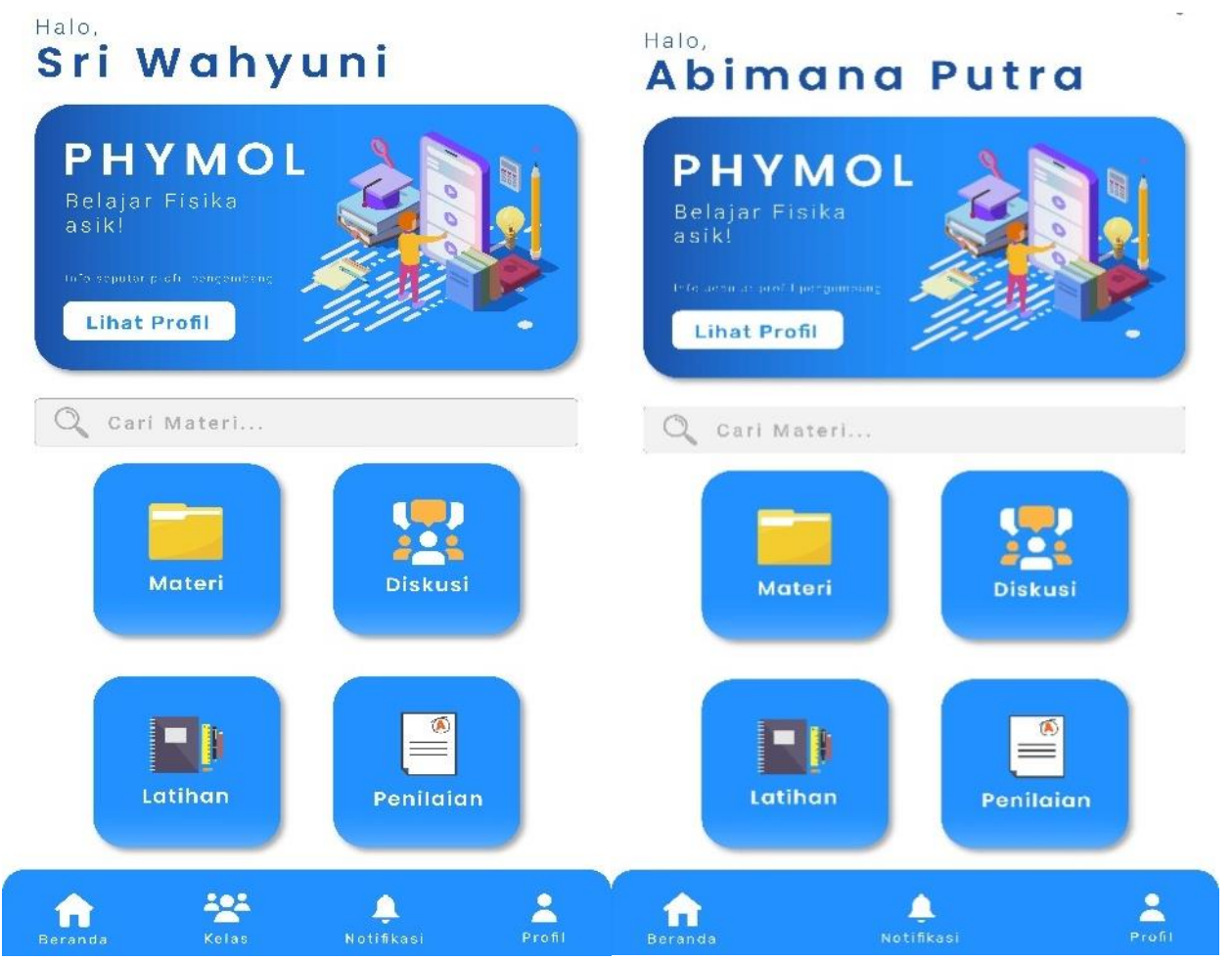

Figure 1. Display of Student's Main Menu and Teacher's Main Menu

\section{Discussion}

This mobile learning research uses RASE framework for menus contained in the mobile learning application, namel; first, resources for material menu consists of thermodynamic learning materials including video, modules, and animation (Churchill, Lu, et al., 2016; Widayanti et al., 2019). Second, Activity for the training menu consists of exercises with the form of multiple choice questions, essays or performance assessments. Third, Support, for discussion menu. In this discussion menu students can discuss about materials or exercises. Fourth, Evaluation, for the assessment menu consisting of multiple choice exam questions, essays or performance assessments. This mobile learning research has a different framework to previous mobile learning research conducted by Ngabekti. In previous mobile learning research, the framework was (1) introduction, goal and steps of learning is presented; (2) learning materials of ecology, narrated video of ecoystem in Wana Wisata Semarang, observation tools, as well as demonstration video on how to use these tools; and (3) evaluation tools such as tests and questionaires (Ngabekti et al., 2019). The mobile learning framework in the previous research did not have a support and activity menu.

Support and activity become important in mobile learning framework because one of the characteristics of mobile devices is connectivity, mobile technology allows learners to share and exchange information with anyone (Arsyad \& Lestari, 2020; Dashtestani, 2013; Parsazadeh et al., 2018). In this case students can exchange information through the discussion menu. In addition, mobile devices must also support learning interactions among members of the learning community (Muswita et al., 2018; Sunismi, 2015). In the activity, students will be directed towards the learning objectives to be achieved and how the problem solving process is carried out. In the activity menu or exercises there are models and approaches to learning used. Mobile learning should be integrated with learning models and approaches (Bano et al., 2018; Irnin Agustina Dwi Astutia, Ria Asep Sumarni, 2017). This mobile learning research combines problem-based learning models and STEM approaches. STEM approach is an intregation between four disciplines namely science, technology, engineering, and mathematics in an interdisciplinary approach and is applied based on real-world context and problem-based learning (Hadiyanti et al., 2021; Torlakson, 2014). Problem-based learning models and STEM approaches are appropriately used for science learning in these physics subjects (Ngabekti et al., 2019).

The problem-based learning model in this research is a combination of problem-based learning model and online problem-based learning model (Arends, 2015; Rahayuni, 2016). In this research using six syntax model problem based learning namely induction PBL, problem solving, problem analysis, assist independent and group investigation, develop and presents artifacts and exhibits, analyzes and evaluates problem-solving processes (Arends, 2015). This learning activity is conducted by students to achieve 
learning objectives. Learning activities are defined as learning experiences that must occur, so that students can understand, test ideas, generalize, and apply their knowledge (Churchill, Lu, et al., 2016; Heong et al., 2011; Ivonne et al., 2020). Combining problem-based learning with a STEM approach to learning activities can improve students' motivation and problem-solving skills (Argaw et al., 2017; Guzey et al., 2016; Parno et al., 2019).

This research aims to integrate physics learning through mobile learning, approaches and learning models. The results of this study showed that students have high motivation, when doing scientific activities, solving problems, and doing engineering in the form of experiments so that students discover new things (Argaw et al., 2017; Guzey et al., 2016). That is what causes the learning outcomes of students to increase which can be seen by most students achieving KKM value. There is also a significant difference between the pretest and postest values (Argaw et al., 2017). Mobile learning is effectively used in science learning when combined with learning approaches and problem-based learning models (Bano et al., 2018; Ngabekti et al., 2019; Nikolopoulou \& Kousloglou, 2019). It is because can improve students' motivation and learning outcomes. Combining the STEM approach and problem-based learning models with mobile learning can be one of the lessons that is suitable for generations.

\section{CONCLUSION}

Based on feasibility tests conducted by learning design experts, media experts and materials experts and effectiveness tests directly using products to real goals, it is obtained that mobile learning applications with STEM approaches are feasible and effectively used in physics learning. Combining the STEM approach and problem-based learning models with mobile learning can be one of the lessons that is suitable for generations. The results of these studies indicate that the development of cross platform mobile learning application with STEM approach is worth and effective in learning physics.

\section{REFERENCES}

Afriyanti, M., Suyatna, A., \& Viyanti. (2021). Design of e-modules to stimulate HOTS on static fluid materials with the STEM approach. Journal of Physics: Conference Series, 1788(1). https: //doi.org/10.1088/1742-6596/1788/1/012032.

Alessi, S. M., \& Trollip, S. R. (2001). Multimedia For Learning: Methods And Development. European Jurnal of Education Studies, 1(1).

Anwar, Y., Selamet, A., Huzaifah, S., \& Madang, K. (2020). Training in developing higher-order thinking based online test instrument for biology teachers in Sekayu City. Journal of Community Service and Empowerment, 1(3), 150-155. https://doi.org/10.22219/jcse.v1i3.12241.

Arends, R. I. (2015). Learning to teach (tenth). McGraw-Hill Education.

Argaw, A. S., Haile, B. B., Ayalew, B. T., \& Kuma, S. G. (2017). The effect of problem based learning (PBL) instruction on students' motivation and problem solving skills of physics. Eurasia Journal of Mathematics, Science and Technology Education, 13(3), 857-871. https://doi.org/10.12973/eurasia.2017.00647a.

Arsyad, M. N., \& Lestari, D. E. G. (2020). Efektifitas penggunaan media mobile learning berbasis android terhadap hasil belajar mahasiswa ikip budi utomo malang. Agastya: Jurnal Sejarah Dan Pembelajarannya, 10(1), 89. https://doi.org/10.25273/ajsp.v10i1.5072.

Astra, I. M., Nasbey, H., \& Nugraha, A. (2015). Development of an android application in the form of a simulation lab as learning media for senior high school students. Eurasia Journal of Mathematics, $\begin{array}{llll}\text { Science } \quad \text { Technology 1081-1088. } & \text { 10 }\end{array}$ https://doi.org/10.12973/eurasia.2015.1376a.

Azizah, R., Yuliati, L., \& Latifah, E. (2015). Kesulitan Pemecahan Masalah Fisika Pada Siswa Sma. Jurnal Penelitian Fisika Dan Aplikasinya (JPFA), 5(2), 44. https://doi.org/10.26740/jpfa.v5n2.p44-50.

Bano, M., Zowghi, D., Kearney, M., Schuck, S., \& Aubusson, P. (2018). Mobile learning for science and mathematics school education: A systematic review of empirical evidence. Computers and Education. https://doi.org/10.1016/j.compedu.2018.02.006.

Bartling, M., Steven, S., Eitzinger, A., \& Atzmanstorfer, K. (2016). Press the Button: Online/Offline Mobile Applications in an Agricultural Context. GI Forum, 1, 106-116. https://doi.org/10.1553/giscience2016.

Bencsik, A., Juhász, T., \& Horváth-Csikós, G. (2016). Y and Z Generations at Workplaces. Journal of Competitiveness, 6(3), 90-106. https://doi.org/10.7441/joc.2016.03.06.

Buchanan, J., Pressick-Kilborn, K., \& Maher, D. (2019). Promoting environmental education for primary school-aged students using digital technologies. Eurasia Journal of Mathematics, Science and 
Technology Education, 15(2). https://doi.org/10.29333/ejmste/100639.

Churchill, D., Fox, B., \& King, M. (2016). Framework for Designing Mobile Learning Environments. In Lecture Notes in Educational Technology. Springer International Publishing, 9789811000256, 3-25. https://doi.org/10.1007/978-981-10-0027-0_1.

Churchill, D., Lu, J., Chiu, T. K. F., \& Fox, B. (2016). Mobile Learning Design. Mobile Learning Design: Theories and Application, 63-82. https://doi.org/10.1007/978-981-10-0027-0.

Darmaji, D., Kurniawan, D. A., Astalini, A., Kurniawan, W., Anwar, K., \& Lumbantoruan, A. (2019). Students' perceptions of electronic's module in physics practicum. Journal of Education and Learning (EduLearn), 13(2), 288-294. https://doi.org/10.11591/edulearn.v13i2.13005.

Darmawan, A., Asa, B. N., Kurniawan, F., Nukhba, R., Albab, U., \& Parno. (2020). Pengembangan Instrumen Tes Pemecahan Masalah bagi Mahasiswa Jurusan Fisika pada Materi Dinamika Partikel. Jurnal Pendidikan Fisika Dan Keilmuan (JPFK), 6(1), 55-64. https://doi.org/10.25273/jpfk.v6i1.5579.

Dashtestani, R. (2013). Implementing mobile-assisted language learning (MALL) in an EFL context: Iranian EFL teachers' perspectives on challenges and affordances. The JALT CALL Journal, 9(2), 149-168. https://doi.org/10.29140/jaltcall.v9n2.153.

Desnita, D., \& Susanti, D. (2017). Science Process Skills-Based Integrated Instructional Materials to Improve Student Competence Physics Education Prepares Learning Plans on Teaching Skills Lectures. Jurnal Penelitian \& Pengembangan Pendidikan Fisika, 3(1), 35. https://doi.org/10.21009/1.03105.

Diani, R., Hartati, N. S., \& Email, C. A. (2018). Flipbook berbasis literasi Islam: Pengembangan media pembelajaran fisika dengan 3D pageflip professional. Flipbook Berbasis Literasi Islam: Pengembangan Media Pembelajaran Fisika Dengan 3D Pageflip Professional, 4(2), 234-244. https://doi.org/10.21831/jipi.v4i2.20819.

Duran, M., Höft, M., Medjahed, B., Lawson, D. B., \& Orady, E. A. (2015). STEM learning: IT integration and collaborative strategies. In STEM Learning: IT Integration and Collaborative Strategies (pp. 1-183). https://doi.org/10.1007/978-3-319-26179-9.

Ekici, E. (2016). "Why Do I Slog Through the Physics?": Understanding high school students' difficulties in learning physics. Journal of Education and Practice, 7(7), 95-107.

Elsayary, A., Forawi, S., \& Mansour, N. (2015). STEM Education and Problem-Based Learning. January.

Felder, R. M., \& Brent, R. (2016). Teaching and Learning STEM: a Practical Guide. Jossey-Bass A Wiley Brand.

García-Martínez, I., Fernández-Batanero, J. M., Sanchiz, D. C., \& de la Rosa, A. L. (2019). Using mobile devices for improving learning outcomes and teachers' professionalization. Sustainability (Switzerland), 11(24), 1-12. https://doi.org/10.3390/su11246917.

Gunada, I. W., Rokhmat, J., Hikmawati, H., \& Kesipudin, K. (2017). Pengembangan Bahan Ajar Kompilasi Fisika Matematika Ii Pokok Bahasan Persamaaan Diferensial Untuk Meningkatkan Penalaran Matematis. Jurnal Pendidikan Fisika Dan Teknologi, 3(2), 216. https://doi.org/10.29303/jpft.v3i2.414.

Gunawan, Harjono, A., Hermansyah, \& Herayanti, L. (2019). Guided inquiry model through virtual laboratory to enhance students' science process skills on heat concept. Cakrawala Pendidikan, 38(2), 259-268. https://doi.org/10.21831/cp.v38i2.23345.

Guzey, S. S., Moore, T. J., Harwell, M., \& Moreno, M. (2016). STEM Integration in Middle School Life Science: Student Learning and Attitudes. Journal of Science Education and Technology, 25(4), 550-560. https://doi.org/10.1007/s10956-016-9612-X.

Hadiyanti, N. F. D., Hobri, Prihandoko, A. C., Susanto, Murtikusuma, R. P., Khasanah, N., \& Maharani, P. (2021). Development of mathematics e-module with STEM-collaborative project based learning to improve mathematical literacy ability of vocational high school students. Journal of Physics: Conference Series, 1839(1). https://doi.org/10.1088/1742-6596/1839/1/012031.

Handayani, D., Elvinawati, E., Isnaeni, I., \& Alperi, M. (2021). Development Of Guided Discovery Based Electronic Module For Chemical Lessons In Redox Reaction Materials. International Journal of Interactive Mobile Technologies (IJIM), 15(07), 94. https://doi.org/10.3991/ijim.v15i07.21559.

Heong, Y. M., Othman, W. B., Yunos, J. B. M., Kiong, T. T., Hassan, R. Bin, \& Mohamad, M. M. B. (2011). The Level of Marzano Higher Order Thinking Skills among Technical Education Students. International Journal of Social Science and Humanity, 1(2), 121-125. https://doi.org/10.7763/ijssh.2011.v1.20.

Irnin Agustina Dwi Astutia, Ria Asep Sumarni, D. L. S. (2017). Pengembangan Media Pembelajaran Mobile Learning Berbasis Android. Jurnal Penelitian \& Pengembangan Pendidikan Fisika, 3(1), 59. https://doi.org/10.21009/jrpk.072.10.

Ivonne, H. P. A., Alberto, M. P. M., \& Guadalupe, C. F. R. (2020). Augmented reality application for teaching basic operations with fractions of the same denominator. Journal of Computer Science, 16(7), 10421062. https://doi.org/10.3844/jcssp.2020.1042.1062.

Juraini, J., Taufik, M., \& Gunada, I. W. (2017). Pengaruh Model Pembelajaran Kooperatif Tipe STAD (Student 
Team Achievement Division) dengan Metode Eksperimen Terhadap Keterampilan Proses Sains dan Hasil Belajar Fisika pada Siswa SMA Negeri 1 Labuapi Tahun Pelajaran 2015/2016. Jurnal Pendidikan Fisika Dan Teknologi. https://doi.org/10.29303/jpft.v2i2.293.

Kattayat, S., Josey, S., \& Asha, J. V. (2017). Mobile learning apps in instruction and students achievement. International Journal of Interactive Mobile Technologies, 11(1), 143-147. https://doi.org/10.3991/ijim.v11i1.6420.

Kortemeyer, G. (2016). The Losing Battle Against Plug-and-Chug. The Physics Teacher, 54(1), 14-17. https://doi.org/10.1119/1.4937964.

Maulina, H., Abdurrahman, A., Sukamto, I., Kartika, N., \& Nurulsari, N. (2020). Z-generation learner characteristic and expectation in the RI 4.0 era: A preliminary research in physics teacher college in Lampung. Journal of Physics: Conference Series, 1572(1), 0-6. https://doi.org/10.1088/17426596/1572/1/012091.

Muswita, Utomo, A. B., Yelianti, U., \& Wicaksana, E. J. (2018). Pengembangan E-Book Berbasis Mobile Learning Pada Mata Kuliah Struktur Tumbuhan. Pendidikan Biologi, 11, 93-104. https://doi.org/10.20961/bioedukasi-uns.v11i2.23814.

Mutakinati, L., Anwari, I., \& Yoshisuke, K. (2018). Analysis of students' critical thinking skill of middle school through stem education project-based learning. Jurnal Pendidikan IPA Indonesia, 7(1), 54-65. https://doi.org/10.15294/jpii.v7i1.10495.

Ngabekti, Prasetyo, Hardianti, \& Teampanpong. (2019). The Development of STEM Mobile Learning Package Ekosistem. Jurnal Pendidikan IPA Indonesia, 8(1), 81-88. https://doi.org/10.15294/jpii.v8i1.16905.

Nikolopoulou, K., \& Kousloglou, M. (2019). Mobile Learning in Science: A Study in Secondary Education in Greece. Creative Education, 10(06), 1271-1284. https://doi.org/10.4236/ce.2019.106096.

Nuraziza, \& Suwarma. (2018). Menggali Keterampilan Creative Problem Solving yang dimiliki Peserta didik SMP melalui Pembelajaran IPA Berbasis STEM. Jurnal WAPFI (Wahana Pendidikan Fisika), 3(1), 5561. https://doi.org/10.17509/wapfi.v3i1.10941.

Parno, Yulianti, L., \& Ni'mah, B. (2019). The influence of PBL-STEM on students ' problem- solving skills in the topic of optical instruments The influence of PBL-STEM on students ' problem-solving skills in the topic of optical instruments. https://doi.org/10.1088/1742-6596/1171/1/012013.

Parsazadeh, N., Ali, R., \& Rezaei, M. (2018). A framework for cooperative and interactive mobile learning to improve online information evaluation skills. Computers and Education, 120(May 2017), 75-89. https://doi.org/10.1016/j.compedu.2018.01.010.

Polyanin, A. D., Chernoutsan, A. I., Egorov, A. ., \& Manzhirov, A. . (2011). A concise handbook of mathematics, physics, and engineering sciences (A. D. Polyanin \& A. I. Chernoutsan (eds.)). CRC Press.

Priani, I., Manuaba, I. B. S., \& Darsana, I. W. (2019). Pengaruh Model Problem Based Learning (PBL) Berbantuan Media Gambar Terhadap Hasil Belajar IPA Siswa Kelas V Gugus III Kuta Utara Tahun Pelajaran 2017/2018. Mimbar PGSD, 7(1). https://doi.org/10.23887/jjpgsd.v7i1.16972.

Rahayuni, G. (2016). Hubungan Keterampilan Berpikir Kritis Dan Literasi Sains Pada Pembelajaran Ipa Terpadu Dengan Model Pbm Dan Stm. Jurnal Penelitian Dan Pembelajaran IPA, 2(2), 131. https://doi.org/10.30870/jppi.v2i2.926.

Rahmat, R. F., Mursyida, L., Rizal, F., Krismadinata, K., \& Yunus, Y. (2019). Pengembangan media pembelajaran berbasis mobile learning pada mata pelajaran simulasi digital. Jurnal Inovasi Teknologi Pendidikan, 6(2), 116-126. https://doi.org/10.21831/jitp.v6i2.27414.

Rante, P., Sudarto, \& Ihsan, N. (2013). Pengembangan multimedia pembelajaran fisika berbasis audio-video eksperimen listrik dinamis di smp. Jurnal Pendidikan IPA Indonesia, 2(2), 203-208. https://doi.org/10.15294/jpii.v2i2.2724.

Roebianto, A. (2020). The Effects of Student's Attitudes and Self-Efficacy on Science Achievement Jurnal Pengukuran Psikologi dan Pendidikan Indonesia. Jurnal Pengukuran Psikologi Dan Pendidikan Indonesia, 9(1), 1-10. https://doi.org/10.15408/jp3i.v9i1.14490.

Sa'diyah, S. (2020). Peningkatan motivasi dan hasil belajar sistem gerak melalui model pembelajaran problem based learning. Journal of Curriculum Indonesia, 3(2), 79. https://doi.org/10.46680/jci.v3i2.32.

Sa'pang, A. W., \& Purbojo, R. (2020). Teacher`s self-efficacy, understanding of students` characters, and understanding of the 21st century skills as predictors of facilitator type of teaching style. Jurnal Psikologi Ulayat: Indonesian Journal of Indigenous Psychology, 7(2), 192-211. https://doi.org/10.24854/JPU108.

Seemiller, Corey, M. G. (2019). Generation $Z$ - a century in the making. Routledge.

Seibert, S. A. (2020). Problem-based learning: A strategy to foster generation Z's critical thinking and perseverance. Teaching and Learning in Nursing, 000, 2-5. 
https://doi.org/10.1016/j.teln.2020.09.002.

Shin, S., Lee, J. K., \& Ha, M. (2017). Influence of career motivation on science learning in Korean high-school students. Eurasia Journal of Mathematics, Science and Technology Education, 13(5), 1517-1538. https://doi.org/10.12973/eurasia.2017.00683a.

Sommerville, I. (2016). Software Engineering (M. Horton, M. Hirsch, \& M. Goldstein (eds.); Tenth). Pearson Education Limited.

Sudana, I., Apriyani, D., \& Nurmasitah, S. (2019). Revitalization of vocational high school roadmap to encounter the 4.0 industrial revolution. Journal of Social Sciences Research, 5(2), 338-342. https://doi.org/10.32861/jssr.52.338.342.

Sudirman, S., Kistiono, K., Akhsan, H., \& Ariska, M. (2020). Pengembangan Instrumen Penilaian Pengetahuan, Sikap Dan Keterampilan IPA Berbasis Berpikir Kritis Pada Konsep Listrik Siswa SMP. Jurnal Inovasi Dan Pembelajaran Fisika. https://doi.org/10.36706/jipf.v7i1.10903.

Sulani, Y. B. D., Tampubolon, T., \& Sembiring, E. B. (2020). Pengaruh Model Problem Based Learning Berbantu Macromedia Flash Terhadap Hasil Belajar Siswa Pada Materi Pokok Fluida Statis Di Kelas X-Mia Semester Ii Man Binjai. Inovasi Pembelajaran Fisika, 8(1). https://doi.org/10.24114/inpafi.v8i1.17598.

Sunismi. (2015). Developing Guided Discovery Learning Materials Using Mathematics Mobile Learning Application As An Alternative Media For The Students Calculus II. Cakrawala Pendidikan, 34(5). https://doi.org/10.21831/cp.v3i3.7340.

Syahrowardi, S., \& Permana, A. H. (2016). Desain Handout Multimedia Menggunakan 3D Pageflip Professional untuk Media Pembelajaran pada Sistem Android. Jurnal Penelitian \& Pengembangan Pendidikan Fisika, 2(1), 89-96. https://doi.org/10.21009/1.02113.

Torlakson, T. (2014). Innovate A Blueprint for STEM Education - Science (CA Dept of Education). Californians Dedicated to Education Foundation, May, 52.

Tseng, T. H., Tai, Y., Tsai, S. P., \& Ting, Y. L. (2018). Students' self-authoring mobile App for integrative learning of STEM. International Journal of Electrical Engineering Education, 1-12. https://doi.org/10.1177/0020720918800438.

Wang, Q. (2018). Core Technologies in Mobile Learning. October, 127-139. https://doi.org/10.1007/978981-10-6144-8_8.

Widayanti, Abdurrahman, A., \& Suyatna, A. (2019). Future Physics Learning Materials Based on STEM Education: Analysis of Teachers and Students Perceptions. Journal of Physics: Conference Series, 1155(1). https://doi.org/10.1088/1742-6596/1155/1/012021.

Zabelina, D. L., \& Silvia, P. J. (2020). Percolating ideas: The Effects of Caffeine on Creative Thinking and Problem Solving. Consciousness and Cognition, 79(February). https://doi.org/10.1016/j.concog.2020.102899.

Zhang, Y. (2015). Handbook of Mobile Teaching and Learning. Springer. https://doi.org/10.1007/978-3642-54146-9. 